\title{
Estuarine processes and their stratigraphic record: paleosalinity and sedimentation changes in the Hudson Estuary (North America)
}

\author{
Stephen F. Pekar ${ }^{\mathrm{a}, \mathrm{b}, *}$, Cecilia M.G. McHugh ${ }^{\mathrm{a}, \mathrm{b}}$, Nicholas Christie-Blick ${ }^{\mathrm{c}}$, \\ Miriam Jones $^{c}$, Suzanne M. Carbotte ${ }^{b}$, Robin E. Bell ${ }^{b}$, Jean Lynch-Stieglitz ${ }^{\mathrm{d}}$ \\ ${ }^{a}$ Queens College School of Earth and Environmental Sciences, CUNY, 65-30 Kissena Blvd., Flushing, NY 11367, USA \\ ${ }^{\mathrm{b}}$ Lamont-Doherty Earth Observatory of Columbia University, Palisades, NY 10964, USA \\ ${ }^{\mathrm{c}}$ Department of Earth and Environmental Sciences and Lamont-Doherty Earth Observatory of Columbia University, Palisades, NY 10964, USA \\ ${ }^{\mathrm{d}}$ School of Earth and Atmospheric Sciences, Georgia Institute of Technology, Atlanta, GA 30332-0340, USA
}

Received 16 June 2003; accepted 28 May 2004

\begin{abstract}
Paleosalinity estimates and rates of sedimentation inferred from core samples from the Hudson estuary for the interval between 6.4 and $1.3 \mathrm{ka}$ indicate a possible role for the estuarine turbidity maximum (ETM) in influencing patterns of estuarine sedimentation at centennial to millennial time scales. Currently in the estuary, sedimentation is localized via sediment trapping particularly in the vicinity of the ETM, 13-26 km upstream from Battery Park (FBP) at the southern tip of Manhattan, in water depths greater than $4 \mathrm{~m}$, and on the western side of the estuary. Data presented in this paper are from cores located within the segment of the estuary 29-50 km FBP. Age constraints are provided by C-14 dating. Paleoenvironmental interpretations are based upon paleosalinity estimates, grain size variability, and sedimentary structures.

Paleosalinity was inferred on the basis of foraminiferal biofacies analysis and a new method for estimating summertime paleosalinity using oxygen isotope measurements in bivalve shell material. The isotopic analysis of a narrow size fraction (1.0$1.7 \mathrm{~mm}$ ) representing summer growth of a single bivalve species (Gemma gemma) reduces the uncertainty related to annual changes in temperature. Data from $\sim 45 \mathrm{~km}$ FBP indicate a gradual decrease in summertime paleosalinity between 6.4 and 2.0 ka from $25-20 \%$ to $15-10 \%$ (the latter is similar to present-day values). These results are consistent with the conclusion of an earlier low-resolution study.

Sedimentation rates are generally low and are similar to the rate of sea-level rise in the Hudson River. Lowest sedimentation rates are noted in short $(<2 \mathrm{~m})$ cores from north of the Tappan Zee Bridge $(40-50 \mathrm{~km}$ FBP from $2.4 \mathrm{ka}$ to present); in shallow water $(\sim 2 \mathrm{~m}$ at mean low water, core SD-11) $\sim 45 \mathrm{~km} \mathrm{FBP}$; and on the eastern side of the estuary from $\sim 50$ to $29 \mathrm{~km}$ FBP. Exceptions are high sedimentation rates (up to four times background) observed in cores from the western flats (SD 30, $45 \mathrm{~km}$ FBP, 4.9 to $3.4 \mathrm{ka}$ ) in water depths of $4 \mathrm{~m}$ and from the western part of the main channel (P21.7 core, $\sim 32 \mathrm{~km}$ FBP, $>2.3$ to $\sim 1.3 \mathrm{ka}$ ).

We hypothesize that the observed pattern in sediment accumulation relates to a location for the ETM some $20 \mathrm{~km}$ upstream of its present position at $3 \mathrm{ka}$. Downstream migration of the ETM since $3 \mathrm{ka}$ is ascribed to shoaling of the estuary, effectively squeezing the marine saltwater wedge in the same direction, and off marginal flats into the channel. Such shoaling would have enhanced the role of waves in mixing marine and fresher surface water, and reduced the effect of the ETM in
\end{abstract}

* Corresponding author. Tel.: +1-718-997-3305; fax: +1-718-997-3299.

E-mail address: spekar@qc1.qc.edu (S.F. Pekar). 
focusing sediment accumulation. The results of this study are consistent with the idea that at any time, estuarine sedimentation is highly localized, suggesting a more complex depositional pattern than previously indicated in estuarine stratigraphic models.

(C) 2004 Elsevier B.V. All rights reserved.

Keywords: Hudson River; estuary; turbidity maximum; paleosalinity; sedimentation; stratigraphy; Holocene

\section{Introduction}

Patterns of sedimentation and salinity variation in modern estuaries are influenced by tides, wave action, fluvial discharge (e.g., Brown et al., 1995), the configuration of the estuary, and sea-level change (e.g., Dalrymple et al., 1992). Sand accumulates at both the mouth of the estuary (from marine sources) and in bayhead deltas. The latter are localized where confined river channels empty into broader bodies of brackish water characterized by finer-grained sedimentation (Dalrymple et al., 1992; Zaitlin et al., 1994). Salinity varies spatially, with depth and as a function of time (Brown et al., 1995), and influences the flocculation of clays. In partially stratified estuaries, an abrupt gradient between marine saline water (seaward and at depth) and river-derived fresh water (upstream and at the surface) leads to the development of excess sediment in suspension (Postma, 1967; Geyer, 1993). The Estuarine Turbidity Maximum (ETM), where the concentration of suspended sediment is greatest, typically develops where the salinity gradient is most pronounced at the upstream end of the saltwater intrusion (Geyer, 1993) or through the middle portion of the salinity intrusion (Geyer et al., 1998). The role of an ETM in influencing the locus of fine-grained sedimentation has been recognized in numerous estuaries (e.g., Geyer, 1993; Uncles and Stephens, 1993; Fenster and FitzGerald, 1996; Le Bris and Glemarec, 1996; Grabemann et al., 1997; Sanford et al., 2001). The convergence of saline bottom water and fresh surface water near the ETM tends to reduce the strength of both flows (Nichols, 1972), and hence to favor the deposition of suspended sediment. Rates of accumulation are as much as two orders of magnitude greater than in other parts of the fluvial-estuarine system (Woodruff et al., 2001).

Although these processes have been studied extensively in modern estuaries, their role at geological time scales is less well established. This is partly due to the lack of appropriate age resolution and partly because it is difficult to quantify paleosalinity in ancient estuarine deposits. If the ETM played a role at those time scales, the locus of sediment accumulation ought to have been influenced by salinity. This paper describes a proxy for the estimation of paleosalinity, an integrated approach using oxygen isotopes and benthic foraminiferal assemblages, with an application to the mid- to late Holocene of the Hudson estuary. Results using paleosalinity estimates combined with lithofacies and age models for cores taken from the Hudson estuary provide evidence that supports the hypothesis that the ETM influenced sedimentation at time scales of up to thousands of years. This suggests a more complex depositional history for estuaries that contain an ETM than indicated in the typical estuarine stratigraphic models.

\section{The Hudson estuary}

The Hudson valley and estuary have witnessed marked environmental changes since the late Pleistocene glacial maximum (19 ka). The valley was incised to a depth of $200 \mathrm{~m}$ below modern sea level in the vicinity of the Tappan Zee Bridge, $45 \mathrm{~km}$ upstream from Battery Park (FBP) at the southern tip of Manhattan, by a combination of glacial and glaciofluvial processes. Retreat of the ice led to the development of a series of moraine-dammed glacial lakes at least as far north as Albany (Uchupi et al., 2001). These lakes were drained, replaced by a throughgoing river system, and flooded by the sea in the vicinity of New York Bay by $12-10$ ka (Weiss, 1974). The Hudson estuary was progressively drowned until 6-7 ka, when paleosalinity reached a maximum value. A decrease in paleosalinity since $6 \mathrm{ka}$ is thought to be due primarily to infilling of the estuary. The late Pleistocene and Holocene evolution of the estuary would also have been influenced by the 
interplay of glacio-isostatic rebound and eustatic rise (Newman et al., 1969; Ridge et al., 1991).

Today, sedimentation in the Hudson estuary is controlled primarily by tides and wave action, fluvial discharge, and dredging. Although the tidal range is only $1-2 \mathrm{~m}$ at the mouth of the estuary, sedimentation is tidally influenced as much as $220 \mathrm{~km}$ upstream FBP. Tidal flows in the lower reaches of the channel are in excess of $1 \mathrm{~m} \mathrm{~s}^{-1}$ (Olsen et al., 1978). Salinity ranges from near marine values in the lower harbor to $\sim 0.5 \%$ o as far as $100 \mathrm{~km}$ north FBP, and varies with the tidal cycle and seasonally (according to runoff).

\subsection{The ETM in the Hudson estuary}

The ETM is a prominent feature in the lower part of the Hudson estuary (Fig. 1), associated with localized concentrations of suspended sediment and elevated rates of sediment accumulation. It encompasses the portion of the estuary in which the greatest salinity gradient is observed, typically between 12 and $26 \mathrm{~km}$ FBP (Geyer et al., 1998), and is similar to turbidity maxima in other estuaries (e.g., James River estuary; Nichols, 1972). It has been shown to be important in fine-grained sedimentation patterns in the Hudson estuary (e.g., Olsen et al., 1978; Geyer, 1993; Woodruff et al., 2001), with among the highest rates of sediment deposition $(10-30 \mathrm{~cm} /$ year) observed. High sedimentation rates are found preferentially on the western side of the estuary (due to the baroclinic pressure gradient and Coriolis acceleration; Geyer et al., 1998), where the estuarine bottom is below wave base ( $>4 \mathrm{~m}, \mathrm{R}$. Geyer, personal communication, 2002). Sedimentation rates at decadal and

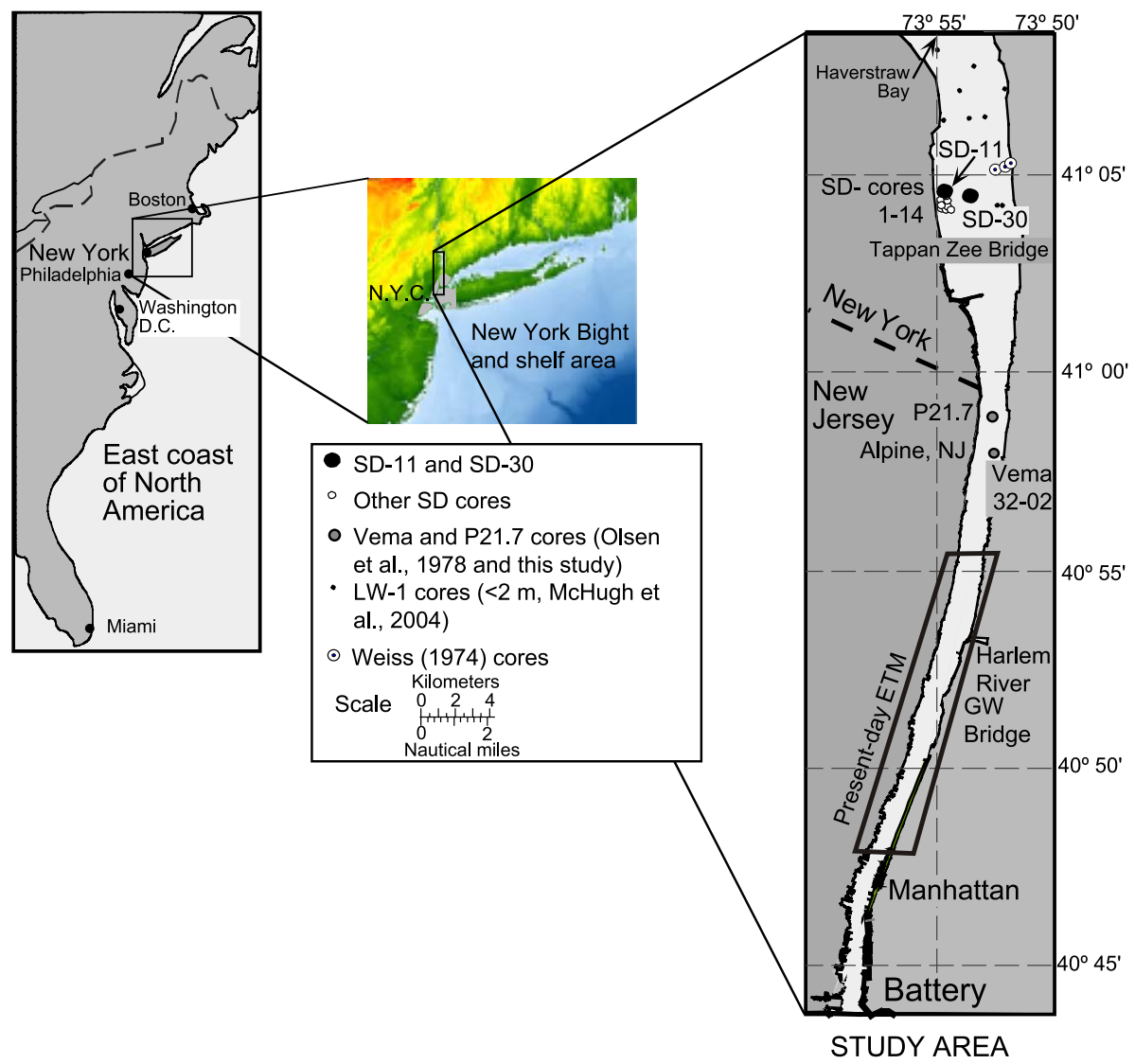

Fig. 1. Map of study area in the lower Hudson estuary showing locations of cores used in this study and location of the present-day ETM. Haverstraw Bay begins just north of the upper portion of this map. 
longer time scales are $\sim 1.3 \mathrm{~cm} /$ year (Geyer et al., 2001), and this results in shoaling beneath the ETM (Coch, 1986; Woodruff et al., 2001). These sedimentation rates are an order of magnitude larger than rates estimated upstream $(\leq 1.0 \mathrm{~mm} /$ year; Olsen et al., 1978; McHugh et al., 2004). In fact, outside of the ETM, sedimentation is localized only in the vicinity of anthropogenic features (e.g., bridge footings) or unusual geomorphic structures (outcrops on the riverbed; McHugh et al., 2004), both of which influence flow patterns.

A combination of marine, estuarine and fluvial processes results in systematic spatial variations in sedimentation. Clay and silt accumulate from south of Kingston $(\sim 150 \mathrm{FBP})$ to near the Tappan Zee area, and on the western side of the estuary as far south as upper New York Bay (Coch, 1986; Woodruff et al., 2001). Sand accumulates mainly north of Kingston, and in channels and on the eastern side of upper and lower New York bays (Coch, 1986). Coarse-grained sediments in the lower part of the estuary are transported mainly by marine processes (tides and waves) from Long Island Sound via the East River (Coch et al., 1991) and from the Atlantic Ocean through the Verrazano Narrows (locations south and east of the area shown in Fig. 1). Coarse-grained sedimentation north of Kingston is controlled by tidal and fluvial processes, and is characterized by sinuous channels and the development of islands. The study area, located in the estuary between 29 and $50 \mathrm{~km}$ FBP, is characterized by the deposition of clay and silt and by a relatively low-energy tidally influenced environment.

\subsection{A paleo-ETM in the Hudson estuary?}

The prominence of the ETM in the Hudson estuary today raises questions regarding whether an ETM may have existed in the past and, if so, about the role it may have played in the development of the long-term sedimentary record of the estuary. Hypothesizing that an ETM was present in the past, where would one look for it in the geologic record; and how might short-term sediment deposition associated with the ETM ultimately become preserved in the long-term record? Published low-resolution studies at centennial to millennium time scales indicate that salinity in the Hudson estuary was higher in the past (Weiss, 1974), and hence that the ETM should have been located farther upstream than it is today. This expectation guided the selection of cores used in this study upstream and on the submerged flats located west of the thalweg.

Salinity profiles in the Hudson estuary in relation to the ETM provide clues about how a paleo-ETM might be expressed in core. Because the ETM is restricted to a particular salinity range, paleosalinity estimates are needed to determine its former location from the sedimentary record. Our data provide a proxy for the summertime salinity range. A useful secondary indicator is anomalously rapid sedimentation on the western side of the estuary in water depths greater than $4 \mathrm{~m}$. The rate of sedimentation inferred in a given core ought to increase upwards in intervals of moderate summertime paleosalinities (low 20s to upper teens), and then decrease as the paleosalinity decreases to the mid- to low teens, corresponding with migration of the ETM downstream from the sampling site. The stratigraphic level of the paleo-ETM inferred in this way from a series of cores is expected to become progressively younger in a seaward direction.

\section{Cores used in this study}

Three long cores $(6-9 \mathrm{~m})$ and six short cores $(<3$ $\mathrm{m})$ from the lower portion of the Hudson estuary were used in this study (Fig. 1). These cores had been obtained for other reasons prior to our research. Therefore their locations, here specified in reference to the distance from Battery Park in Manhattan (FBP), are not necessarily ideal for this study, but still provide sufficient coverage within the study area to ascertain the overall sedimentation and paleosalinity patterns of this portion of the estuary. Two long cores are located in the Tappan Zee area (45 km FBP), one near the western shore (SD-11), and the other close to the channel margin (SD-30; Fig. 1). The Vema 32-02 core is located in the thalweg near the eastern margin of the channel (29 km FBP; Olsen et al., 1978). Data were obtained also from long cores from the eastern side of the estuary in the Tappan Zee area $44-48 \mathrm{~km}$ FBP (Weiss, 1974), from short cores $(<3 \mathrm{~m})$ north of the Tappan Zee Bridge (45-50 km FBP; McHugh et al., 2004), and from $\sim 32 \mathrm{~km} \mathrm{FBP}$ in the channel (Olsen et al., 1978). 


\section{Methods}

In this study, paleosalinities were estimated using benthic foraminiferal biofacies and $\delta^{18} \mathrm{O}$ fromo bivalves. Carbon-14 dating provided the age control, with reservoir offset corrections for C-14 dates obtained from shell material corresponding with brackish water. Water-depth changes were estimated using sedimentation rates from cores and sea-level changes from Peltier (1998).

\subsection{Paleosalinity estimates from benthic foraminiferal biofacies}

Paleosalinity was estimated on the basis of the relative abundance in samples of benthic foraminiferal assemblages similar to modern assemblages of known salinity tolerance in several comparable estuaries including the Hudson itself (Weiss, 1976; Banner and Culver, 1978; Scott et al., 1977, 1980; Buzas et al., 1985; Murray, 1991). Benthic foraminifers were identified using the taxonomy of Parker (1952), Buzas (1965a,b), Todd and Low (1981), Buzas et al. (1985), and Loeblich and Tappan (1988). Four assemblages were recognized: agglutinated spp., Haynesina spp., Elphidium spp., and Ammonia spp. assemblages.

The agglutinated assemblage consists mainly of Trochammina spp. and Ammoscalaria spp., and is inferred to have lived in brackish water with a paleosalinity of between $7 \%$ and $15 \%$ o (11\%o mean value; Ellison and Nichols, 1976; Weiss, 1976; Murray, 1991). This estimate is based on studies that show that calcareous foraminifers are typically intolerant of salinities less than $15 \%$, while agglutinated foraminifers continue to live (and flourish) in salinities as low as $5 \%$. The Haynesina assemblage is inferred to indicate a paleosalinity range of between $14 \%$ and $22 \%$ ( $18 \%$ o mean value). Haynesina spp. is a taxon commonly found in estuaries in the transition between brackish and more open-marine conditions (Scott et al., 1977; Murray, 1991). The assemblage consists of Haynesina obliculare, Haynesina germanica, and agglutinated taxa with low abundances of Elphidium barletti and other Elphidium species. The Elphidium assemblage is inferred to characterize salinities of $14-30 \%$ (22\%o mean value; Weiss, 1976; Weiss et al., 1975; Murray, 1991). Elphidium gunteri, Elphidium margaritaeum, and Elphidium brooklynense dominate the assemblage. The Ammonia spp. assemblage consists primarily of Ammonia beccarii and Ammonia tepida, with minor amounts of Elphidium spp., Buccella frigida, and rare species typical of more open-marine conditions (e.g., Bolivina spp., etc.). This assemblage is typically observed today in the southern portion of New York Harbor (where salinities are near 25\%o; Weiss, 1974, 1976). The paleosalinity range for the assemblage is estimated to be between $18 \%$ and $32 \%$ o (25\%o mean value).

A paleosalinity estimate was obtained for each sample by summing the product of the salinity represented by each foraminiferal assemblage and the fraction of that assemblage in the sample. The results, which are subject to appreciable uncertainty owing to the environmental tolerance of the groups used, can be compared with estimates based on the analysis of oxygen isotopes.

\subsection{Comparison with oxygen isotope data}

Oxygen isotope data can be used to estimate salinity in estuaries owing to the marked contrast between fresh water $\delta^{18} \mathrm{O}$ values (between $-9 \%$ and $-7 \%$ ) and values associated with open marine water (close to zero). Salinity is influenced by variations in fluvial discharge and rainfall, which tends to increase variance in isotopic data, but the most significant source of isotopic variation in non-tropical estuaries relates to seasonal temperature change.

In an attempt to minimize this effect, data were obtained from a narrow size fraction $(1.0-1.7 \mathrm{~mm})$ of a single species of bivalve (Gemma gemma). Today, G. gemma is most abundant in Raritan Bay ( $\sim 30 \mathrm{~km}$ south FBP), at depths of a few meters below mean low water (MLW), and in water with a salinity of 24-27\%o (Selmer, 1959) and has been reported elsewhere to be associated with polyhaline to upper mesohaline environments $(\sim 14-35 \%$ o salinity; Ristich et al., 1977). This species is abundant in cores used in our study, and the size fraction selected makes it possible to limit sampling to early summer to early autumn first-year growth (Bradley and Cooke, 1957; Selmer, 1967; Green and Hobson, 1970). This is important because larger specimens $(>2 \mathrm{~mm}$ ), those with two or more years of growth, contain a significant amount of shell material secret- 
ed in the spring of the second and subsequent years, when both temperature and salinity are expected to have been significantly different. Use of such specimens would result in an isotopic offset of about $0.8 \%$ o between different size fractions (Fig. 2). The use of monospecific samples is important because isotopic offsets also vary between species (at least 0.6\%; Owen et al., 2002). Ignoring these considerations would result in a combined uncertainty of at least $1.4 \%$, which is almost half of the entire range in $\delta^{18} \mathrm{O}$ values $(3.3 \%$ ) documented in this study. Average summertime temperature is estimated to be $22 \pm 3$ ${ }^{\circ} \mathrm{C}$ based on a range in the modern estuary between $19{ }^{\circ} \mathrm{C}$ in the early summer and a maximum of $\sim 24$ $25{ }^{\circ} \mathrm{C}$. This results in an uncertainty in paleosalinity estimates of $\pm 3 \%$ o.

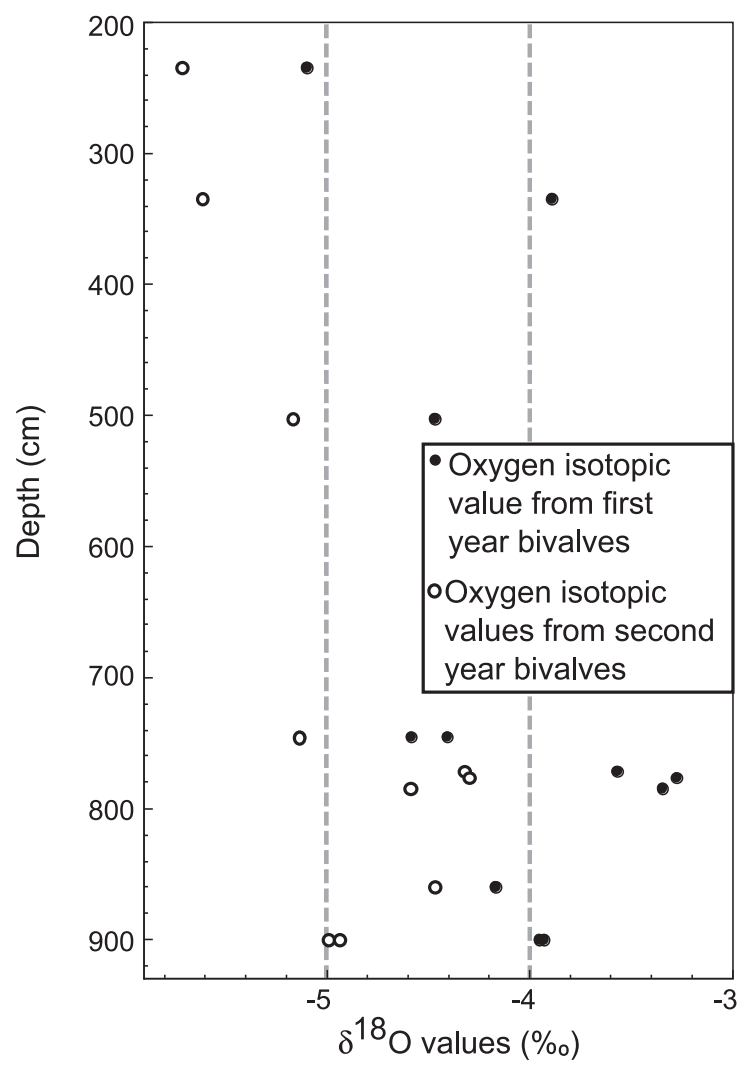

Fig. 2. Oxygen isotopic offsets are compared between first and second year bivalve species, G. gemma in the SD-30 core. An average offset of $\sim 0.8 \%$ in the isotopic values exists between second- and first-year bivalves.
Contaminants were removed from the mollusk shells by dipping them in dilute $\mathrm{HCl}$. Stable isotope measurements on $50-100 \mu \mathrm{g}$ of shell material were made on a Micromass Optima mass spectrometer with Multiprep carbonate preparation device. Oxygen isotope values were calibrated using NBS-19 and NBS18. Replicate measurements on an in-house carbonate standard show a $1 \sigma$ standard deviation in $\delta^{18} \mathrm{O}$ better than $0.08 \%$ o.

A linear relationship between $\delta^{18} \mathrm{O}$ and the salinity of the water is assumed (Fig. 3), and constrained by $\delta^{18} \mathrm{O}$ and salinity values from seawater and from the Hudson estuary near Iona Island (Fairbanks, 1982) and salinity data (McHugh, unpublished data) from surface waters from Iona Island obtained in late October. Paleosalinity estimates obtained in this way from $\delta^{18} \mathrm{O}$ are consistent with those obtained from benthic foraminiferal biofacies, within the uncertainties of methods used. First-order features in both records agree well.

\subsection{Carbon-14 dating}

Developing age models in estuarine sediments using C-14 dates is problematic owing to the incorporation of old carbon into shell material and the salinity dependence of the necessary reservoir correction. The standard marine $\mathrm{C}-14$ offset is 400 year (Broecker, 1963). The correction in water of lower salinity is significantly larger but not well known. We assumed a linear relation between the marine offset and a C-14 date of 1230 years (D.M. Peteet and J.L. Rubenstone, personal communication, 2004) obtained from a pre-bomb ${ }^{1}$ bivalve shell from the Hudson River near Haverstraw Bay ( $\sim 60$ km FBP; average salinity, $\sim 6 \%$ o). The uncertainty in age associated with this correction for varying salinity is \pm 60 year. Shell material used in this study for C-14 dating is from monospecific specimens (G. gemma) and a narrow size range. Carbon-14 ages from other studies listed in Table 1 used shell material from unspecified bivalves. This may increase the error in the reservoir

\footnotetext{
1 Atmospheric nuclear bomb testing has increased C-14 in the atmosphere significantly, limiting the use of C-14 ages for dating since the 1940s. To calibrate C-14 reservoir offsets, shell material must be older than this time.
} 


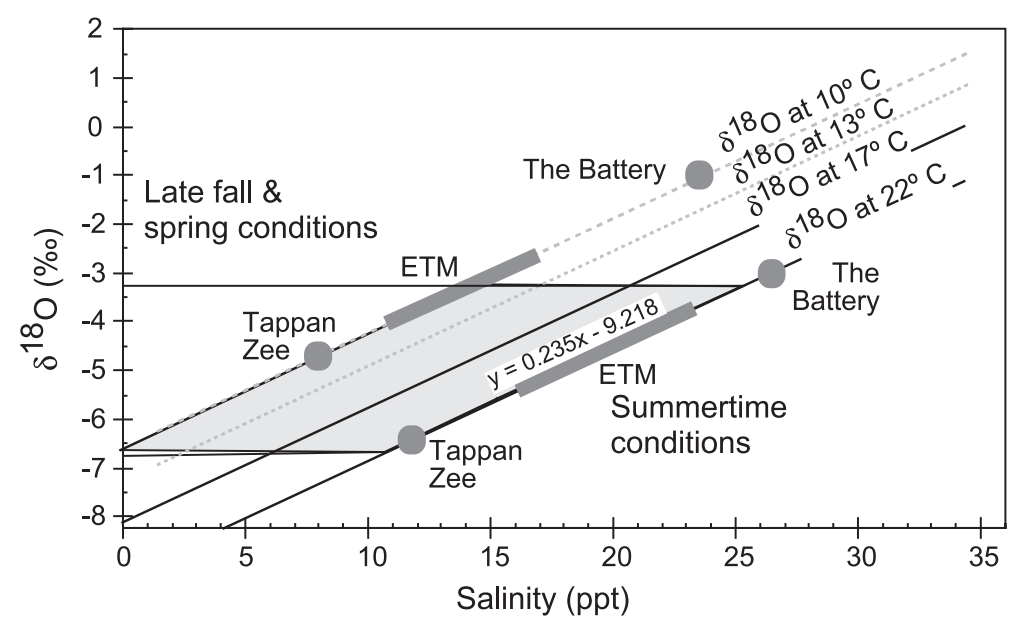

Fig. 3. Salinity relationship to $\delta^{18} \mathrm{O}$ is shown. The different regressions show the $\delta^{18} \mathrm{O}$ and salinity relationship at specific temperatures. The regression uses open marine values and $\delta^{18} \mathrm{O}$ values (Fairbanks, 1982) and salinity data (McHugh, unpublished data) from surface waters from Iona Island obtained in late October. The gray shaded area is bounded by the range in oxygen isotope values from this study and the temperature range that G. gemma lives and shows the range in salinities that are possible for the data from this study. Based on data obtained from the Hudson estuary (e.g., Weiss et al., 1975; Ashkan, unpublished data), a $22 \pm 3{ }^{\circ} \mathrm{C}$ temperature was used to estimate summer time salinity.

correction due to the uncertainty when the precipitation of the calcite occurred. Carbon-14 dates obtained from plant material do not require the same reservoir correction, but they are subject to uncertainty about the timing of deposition and burial compared with the time at which the plant died. All C-14 ages were converted to calendar years based on Stuiver et al. (1998). Carbon-14 dates obtained from shell and wood material were processed at the National Ocean Sciences Accelerator Mass Spectrometry Facility (NOSAMS) using a VG Prism mass spectrometer, with an analytical uncertainty of \pm 35 to \pm 65 years.

\subsection{Constraints on water-depth changes}

Water-depth changes were estimated by comparing sedimentation rates inferred from the cores with sealevel changes implied for the Hudson River by the models of Peltier (1998). The latter take into account the mantle flow and vertical motions of the lithosphere engendered by glacial retreat and unloading (Peltier, 1999). It is not possible to measure waterdepth changes directly with any confidence using foraminiferal assemblages or lithofacies because in estuarine settings these proxies are influenced strongly by other factors (e.g., salinity for foraminifers and energy of the system for lithofacies).

\section{Results}

\subsection{Estimates of paleosalinity and sedimentation rates from cores}

A combination of benthic foraminiferal data and $\delta^{18} \mathrm{O}$ measurements in bivalves from Hudson estuary cores indicate that paleosalinity decreased systematically during the mid- to late Holocene. Corresponding sedimentation rates were generally low $(\sim 1.0 \mathrm{~mm} /$ year or less), with two notable exceptions: the interval between 4.9 and $3.4 \mathrm{ka}$ in core SD-30 (western flats; water depth of $4 \mathrm{~m}$ ), and between 2.3 and $1.3 \mathrm{ka}$ on the western flank of the channel (core P21.7; Fig. 1).

\subsubsection{SD-30 core}

Core SD-30, collected near the channel margin in the Tappan Zee area, is divisible into three intervals on the basis of sedimentation rates and inferred paleosalinity. The lowest interval $(931-700 \mathrm{~cm} ; 6.4-4.9 \mathrm{ka})$ is characterized by high paleosalinities $(15-26 \%$ ) and variable sedimentation rates (0.9-2.4 mm/year; Fig. 4). Isotopic data and foraminifers provide similar paleosalinity estimates (averages of $21 \%$ and $23 \%$, respectively). The sediments are highly bioturbated, with the most abundant shell concentrations in the core found below a depth of $765 \mathrm{~cm}$. Shell material consists mainly 
Table 1

Carbon-14 ages, reservoir offsets and calendar years

\begin{tabular}{|c|c|c|c|c|c|c|c|c|c|c|c|}
\hline & Sample & Source & $\begin{array}{l}\text { Uncorrected } \\
\mathrm{C}-14 \text { dates }\end{array}$ & $\pm 1 \sigma$ & Low age & $\begin{array}{l}\text { High } \\
\text { age }\end{array}$ & Salinity & $\begin{array}{l}\text { Age offset } \\
\text { via salinity }\end{array}$ & $\begin{array}{l}\text { Age with } \\
\text { reservoir } \\
\text { correction }\end{array}$ & $\begin{array}{l}\text { C-14 } \\
\text { offset }\end{array}$ & $\begin{array}{l}\text { Calendar } \\
\text { age }\end{array}$ \\
\hline \multirow[t]{11}{*}{ SD-30 } & 8.0 & $\mathrm{a}$ & 1940 & 35 & 1905 & 1975 & 12 & 1052 & 888 & -112 & 776 \\
\hline & 70.0 & $\mathrm{a}$ & 2370 & 35 & 2335 & 2405 & 12 & 1052 & 1318 & -69 & 1249 \\
\hline & 202.0 & $\mathrm{a}$ & 3730 & 50 & 3680 & 3780 & 18 & 874 & 2856 & 102 & 2958 \\
\hline & 254.0 & $\mathrm{~b}$ & 4100 & 35 & 4065 & 4135 & 20 & 815 & 3285 & 217 & 3502 \\
\hline & 284.0 & $\mathrm{a}$ & 4160 & 35 & 4125 & 4195 & 20 & 815 & 3345 & 205 & 3550 \\
\hline & 466.0 & $\mathrm{~b}$ & 3785 & 40 & 3745 & 3825 & wood & & 3785 & 420 & 4205 \\
\hline & 530.0 & $\mathrm{a}$ & 4800 & 65 & 4735 & 4865 & 20 & 815 & 3985 & 460 & 4445 \\
\hline & 574.0 & $\mathrm{a}$ & 4820 & 65 & 4755 & 4885 & 20 & 815 & 4005 & 410 & 4415 \\
\hline & 695.0 & $\mathrm{a}$ & 5060 & 40 & 5020 & 5100 & 21 & 785 & 4275 & 568 & 4843 \\
\hline & 780.0 & $\mathrm{~b}$ & 5840 & 354 & 5486 & 6194 & 22 & 756 & 5084 & 791 & 5875 \\
\hline & 920.0 & $\mathrm{a}$ & 6270 & 35 & 6235 & 6305 & 24 & 696 & 5574 & 828 & 6402 \\
\hline \multirow[t]{5}{*}{ SD-11 } & 30.0 & $\mathrm{~b}$ & 190 & 40 & 150 & 230 & wood & & 190 & 0 & 190 \\
\hline & 314.0 & $\mathrm{c}$ & 4230 & 40 & 4190 & 4270 & 18 & 874 & 3356 & 241 & 3597 \\
\hline & 348.5 & $\mathrm{~b}$ & 4320 & 40 & 4280 & 4360 & 21 & 785 & 3535 & 255 & 3790 \\
\hline & 731.0 & $\mathrm{~b}$ & 5850 & 110 & 5740 & 5960 & 25 & 667 & 5183 & 791 & 5974 \\
\hline & 760.0 & $\mathrm{c}$ & 6295 & 40 & 6255 & 6335 & 22 & 756 & 5539 & 778 & 6317 \\
\hline \multirow[t]{8}{*}{ Vema $32-02$} & 5.0 & d & 0 & 0 & 0 & 0 & 23 & 726 & 0 & & 0 \\
\hline & 10.0 & $\mathrm{~b}$ & 700 & 85 & 615 & 785 & 24 & 696 & 4 & & 4 \\
\hline & 110.0 & $\mathrm{~d}$ & 1120 & 300 & 820 & 1420 & 27 & 607 & 513 & 8 & 521 \\
\hline & 128.0 & d & 1500 & 130 & 1370 & 1630 & 27 & 607 & 893 & -47 & 846 \\
\hline & 200.0 & d & 2210 & 370 & 1840 & 2580 & 27 & 607 & 1603 & -117 & 1486 \\
\hline & 254.0 & $\mathrm{~b}$ & 2490 & 35 & 2455 & 2525 & wood & & 2490 & 8 & 2498 \\
\hline & 266.0 & d & 2080 & 270 & 1810 & 2350 & 27 & 607 & 1473 & outlier & \\
\hline & 560.0 & $\mathrm{~b}$ & 4760 & 60 & 4700 & 4820 & 27 & 607 & 4153 & 638 & 4791 \\
\hline \multirow[t]{3}{*}{ P21.7 } & 37.5 & $\mathrm{~d}$ & 2240 & 40 & 2200 & 2280 & 23 & 726.1 & 1514 & -95 & 1419 \\
\hline & 135.0 & d & 2740 & 40 & 2700 & 2780 & 23 & 726.1 & 2014 & -18 & 1996 \\
\hline & 205.0 & d & 2980 & 40 & 2940 & 3020 & 25 & 667 & 2313 & -45 & 2268 \\
\hline
\end{tabular}

Source of C-14 dates. (a) Peteet and Rubenstone (in preparation). (b) This study. (c) Carbotte et al. (in press). (d) Olsen et al. (1978). Carbon-14 ages obtained in this study used shell material from monospecific G. gemma specimens from a narrow size range (1.0-1.7 mm). Carbon-14 ages from other studies used shell material from unspecified bivalve species.

of small $(<1 \mathrm{~cm})$ bivalves and gastropods, typically representing up to $50 \%$ of the sediments by weight in that part of the core. The dominant species of bivalves are G. gemma and Mulinia lateralis, both of which are common in estuaries and characteristic of upper mesohaline to polyhaline environments $(\sim 14-35 \%$ o paleosalinity; Ristich et al., 1977; Weiss et al., 1978).

The overlying interval $(700-223 \mathrm{~cm} ; 4.9$ to $3.4 \mathrm{ka})$ is characterized by higher sedimentation rates (an increase from 0.9 to $3.2 \mathrm{~mm} /$ year; Fig. 4) and paleosalinity estimates ranging from $15 \%$ o to $26 \%$, averaging $19 \%$ o from isotopes and $18 \%$ from foraminifers. The uppermost interval $(223-0 \mathrm{~cm} ; 3.4$ to $<2.6 \mathrm{ka})$ is associated with a marked decrease in sedimentation rate, from 3.2 $\mathrm{mm} /$ year to $0.8 \mathrm{~mm}$ with paleosalinities decreasing from around $20 \%$ o to $15-10 \%$ o by $158 \mathrm{~cm}$ (2.6 ka; Fig. 4$)$. The sedimentation rate is similar to the rate of sea-level rise modeled by Peltier (1998). Average paleosalinity estimates for this interval are $17 \%$ o from isotopes and $15 \%$ from foraminifers.

\subsubsection{SD-11 core and cores north and east of the $S D$ cores}

Sedimentation rates for SD-11 range from $1.7 \mathrm{~mm} /$ year (between 6.3 and $3.6 \mathrm{ka}$ ) to $1.0-0.7 \mathrm{~mm} /$ year (from 3.6 ka to present), and generally track the sea-level rise modeled by Peltier (1998; 1.4-0.8 mm/year; Fig. 5). The high rates documented in SD-30 are not observed in the SD-11 core. Paleosalinity estimates range from $19 \%$ o to $24 \%$ o between 757 and $480 \mathrm{~cm}$, and from $14 \%$ o to $21 \%$ o between 480 and $181 \mathrm{~cm}$. No benthic foraminifers were available in the upper $180 \mathrm{~cm}(1.9 \mathrm{ka}$ 


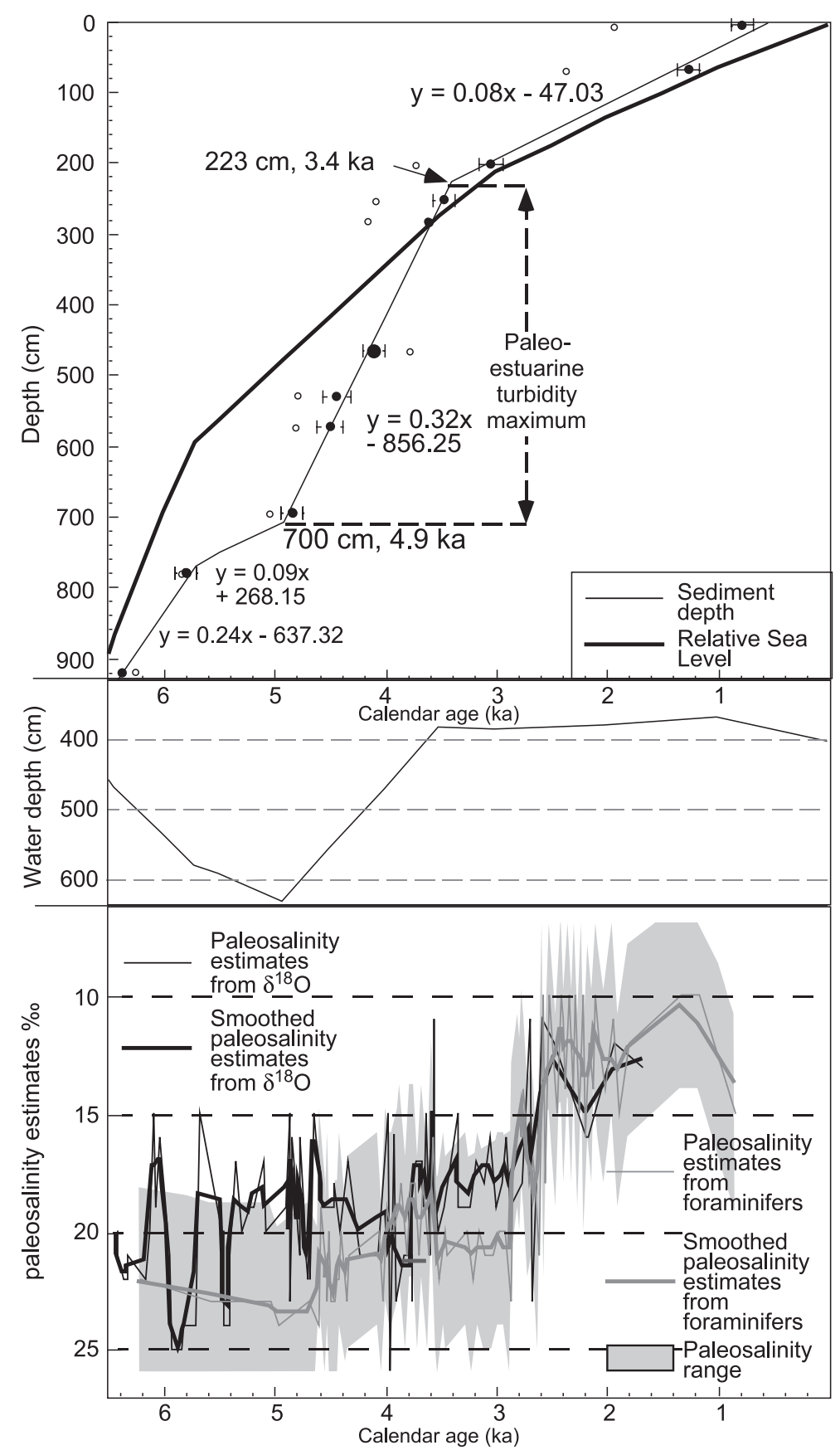

Fig. 4. Summary figure for SD-30. The upper part of this figure shows the age model for the SD-30 core (thin black line) and relative sea-level curve (thick black line) based on Peltier (1998). Linear regressions for sedimentation rates are shown for each interval. Small black circles represent calendar ages converted from C-14 ages obtained from shell material (corrected for reservoir offsets) and the large black circle represents a calendar age converted from a C-14 age from plant material. Non-filled circles are uncorrected C-14 ages. The middle part of this figure shows water-depths for the SD-30 core (present day water depth at SD-30 is $\sim 4.0 \mathrm{~m}$, mean low tide). Water depths were determined by taking the difference between the sea-level estimates for the Hudson River from Peltier (1998) and the sedimentation history of SD-30. The lower part of this figure are paleosalinity estimates based on foraminifers and oxygen isotopes. 


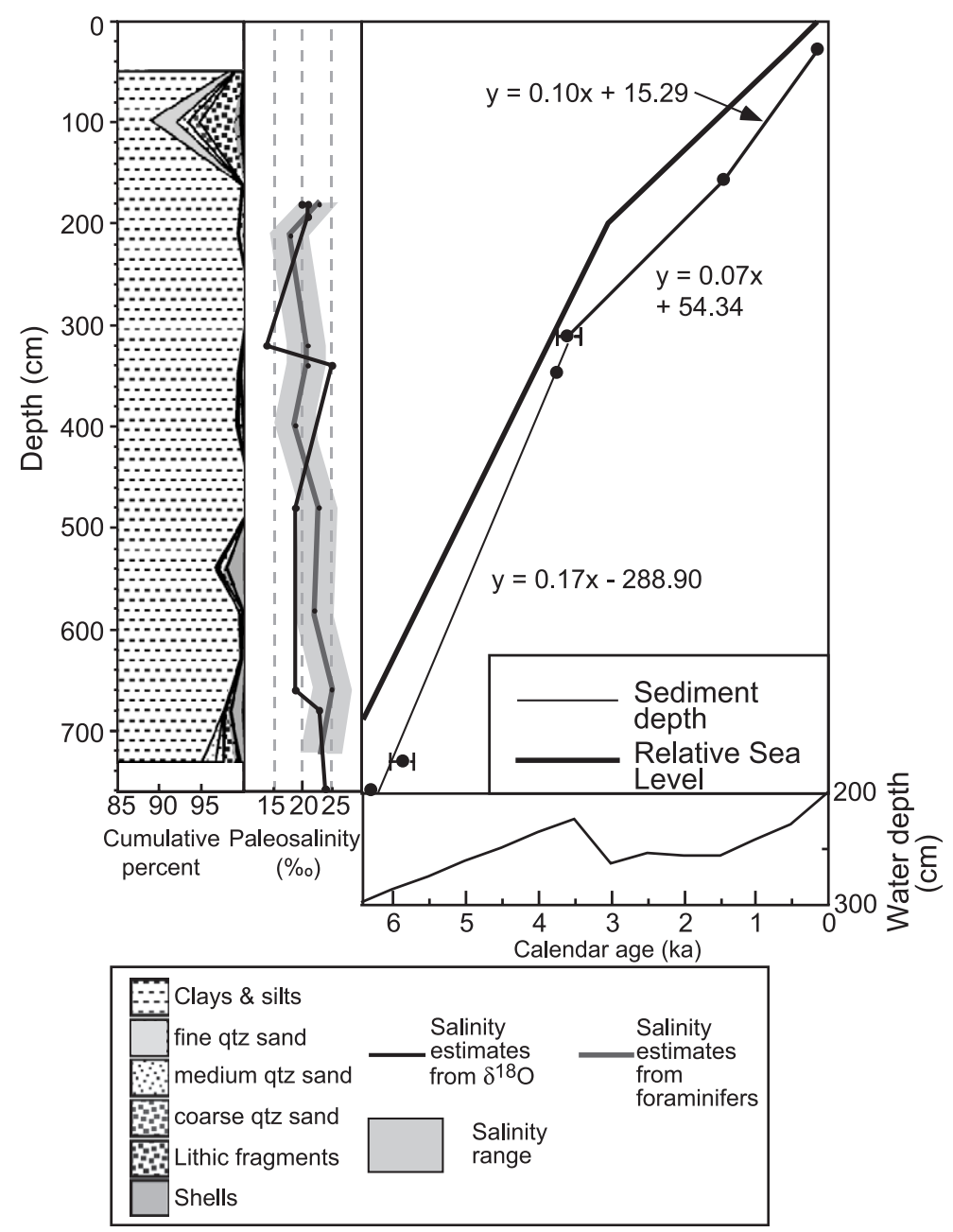

Fig. 5. Summary figure for SD-11. The sediment cumulative percent is compared to paleosalinity estimates based on foraminiferal assemblages (dark gray line with range in light gray) and oxygen isotopes (black line) and the age model based on C-14 dates. Changes in sedimentation rates and linear regressions are shown for each interval.

to present) to estimate paleosalinity. This may be due to low salinities or other paleoenvironmental conditions adverse to these organisms.

Short $(<2 \mathrm{~m})$ cores acquired north of the SD cores are characterized by little to no deposition $(\leq 1.0 \mathrm{~mm} /$ year) for at least the past $1.0 \mathrm{ky}$ (McHugh et al., 2004), and by low paleosalinity $(<15 \%)$ throughout. Ages for these cores date back to $2.4 \mathrm{ka}$, suggesting relatively slow sedimentation rates. Long cores on the eastern side of the estuary in the Tappan Zee area show generally slow sedimentation and decreasing salinities through time (Weiss, 1974).

\subsubsection{Vema 32-02 and P21.7 cores}

Sedimentation and paleosalinity estimates for most of the Vema 32-02 core show the least variability among the three long cores (Fig. 6). Foraminifers and stable isotope data indicate average summertime paleosalinities in the mid-20's to upper teens for the entire core. Sedimentation rates are relatively low between $603 \mathrm{~cm}$ (base of the core) and $120 \mathrm{~cm}$, ranging from 1.4 to $0.6 \mathrm{~mm} /$ year. These rates are similar to the rate of sea-level rise of Peltier (1998; $1.4-0.8 \mathrm{~mm} /$ year), resulting in little change in water depth. However, the upper $100 \mathrm{~cm}$ was deposited more 


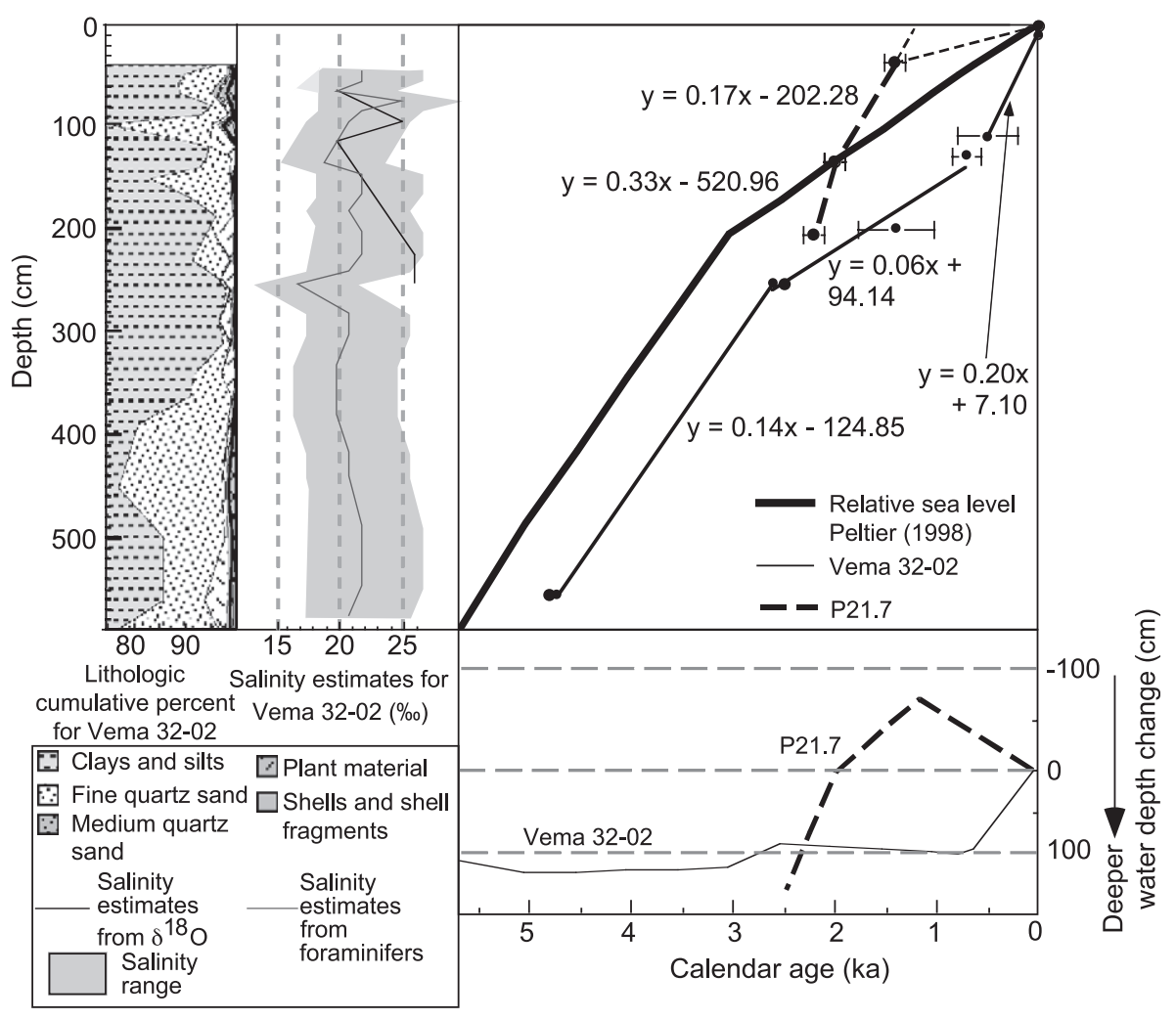

Fig. 6. Summary diagram for Vema 32-02 and P21.7 cores. For Vema 32-02, the sediment cumulative percent is compared to paleosalinity estimates based on foraminiferal assemblages (dark gray line) and oxygen isotopes (black line) and the age model based on C-14 dates. C-14 dates are from this study and Olsen et al. (1978) (Table 1). For core P21.7, two possible sedimentation rates younger than 1.3 ka are shown: 1) sedimentation continues at $1.7 \mathrm{~mm} /$ year and then ends abruptly at $1.2 \mathrm{ka}$; and 2$)$ slow sedimentation $(<0.3 \mathrm{~mm} /$ year $)$ to present. The lower part of this figure shows water-depth changes for the Vema 32-02 and P21.7 cores compared to present day.

rapidly ( $2 \mathrm{~mm} /$ year), leading to an $\sim 0.8 \mathrm{~m}$ decrease in water depth within the past 500 years.

A short $(<3 \mathrm{~m})$ core $(\mathrm{P} 21.7)$ obtained by Olsen et al. (1978) from the main channel, $\sim 3 \mathrm{~km}$ north of Vema 32-02, records moderately high sedimentation rates $(3.3-1.7 \mathrm{~mm} /$ year) until $\sim 1.3 \mathrm{ka}$, and very low rates thereafter $(<0.3 \mathrm{~mm} /$ year; Olsen et al., 1978). Paleosalinity studies were not undertaken for this core.

\section{Sedimentation patterns and paleosalinity changes in the Hudson estuary: evidence for a paleo-ETM}

Results from this study suggest that sedimentation rates were comparable to the rate of sea-level rise (based on Peltier, 1998) over broad areas in the estuary (Figs. 5 and 6), with high rates restricted to relatively short time intervals on the flats west of the channel (in water depths $>4 \mathrm{~m}$ at $45 \mathrm{~km}$ FPB between 4.9 and 3.4 ka; Fig. 4), and in the western part of the channel (32 km FBP between $>2.3$ and $1.3 \mathrm{ka}$ ). In contrast, modern sedimentation is exceedingly patchy, and localized via sediment trapping particularly in the vicinity of the ETM (between 13 and $26 \mathrm{~km} \mathrm{FBP}$ ) on the western side of the estuary in water depths greater than $4 \mathrm{~m}$ (Woodruff et al., 2001). Our data reveal a decline in the paleosalinity of the Hudson estuary from the mid- to late Holocene, from the low 20's to between $10 \%$ and $15 \%$ at SD-30, and from the midteens to $<10 \%$ o farther upstream in Haverstraw Bay (Weiss, 1974).

A comparison between paleosalinity and sedimentation rates inferred for SD-30 and the patterns ob- 
served today suggests that the paleo-ETM may have influenced sedimentation at geological time scales. Elevated sedimentation rates at SD-30 date to $4.9 \mathrm{ka}$ and are associated with a summertime paleosalinity between $15 \%$ and $26 \%$, comparable with summertime salinities observed near the seaward limit of the contemporary ETM (Fig. 7). Laminated sediments are common within this interval, suggesting that sedimentation rates were sufficiently high to limit bioturbation. A decrease in the rate of sedimentation at $\sim 3.4$ $\mathrm{ka}$ (from 3.2 to $0.8 \mathrm{~mm} / \mathrm{year}$ ) coincides with a decrease in summertime paleosalinity from $\sim 20 \%$ o to the low teen's by $2.6 \mathrm{ka}$, a value that is consistent with the summertime salinity near the upstream limit of the ETM.

Bivalve abundances also provide evidence for variations in turbidity and the rate of sedimentation. The interval of highest sedimentation rate in SD-30
$(700-220 \mathrm{~cm})$ is characterized by a diminished abundance of G. gemma abundance and the absence of oysters (species Crassostrea virginica). Both species are susceptible to turbidity, which is typically associated with high sediment flux (Selmer, 1959). The rate of sedimentation in the vicinity of the modern ETM $(<30 \mathrm{~cm}$ in a season; Woodruff et al., 2001) is sufficient to blanket the hard substrate that oysters need for successful setting of spats and to bury the tiny shells of G. gemma.

High rates of sedimentation appear to have been spatially limited and to have migrated seaward through time. They are noted in the Tappan Zee area $(\sim 45 \mathrm{~km} \mathrm{FBP})$ between 4.9 and $3.4 \mathrm{ka}$, in the vicinity of Alpine (core P21.7; $32 \mathrm{~km} \mathrm{FBP}$ ) no later than $2.3 \mathrm{ka}$ (base of the core) to $1.3 \mathrm{ka}$, and today between 26 and $13 \mathrm{~km}$ FBP (Woodruff et al., 2001).

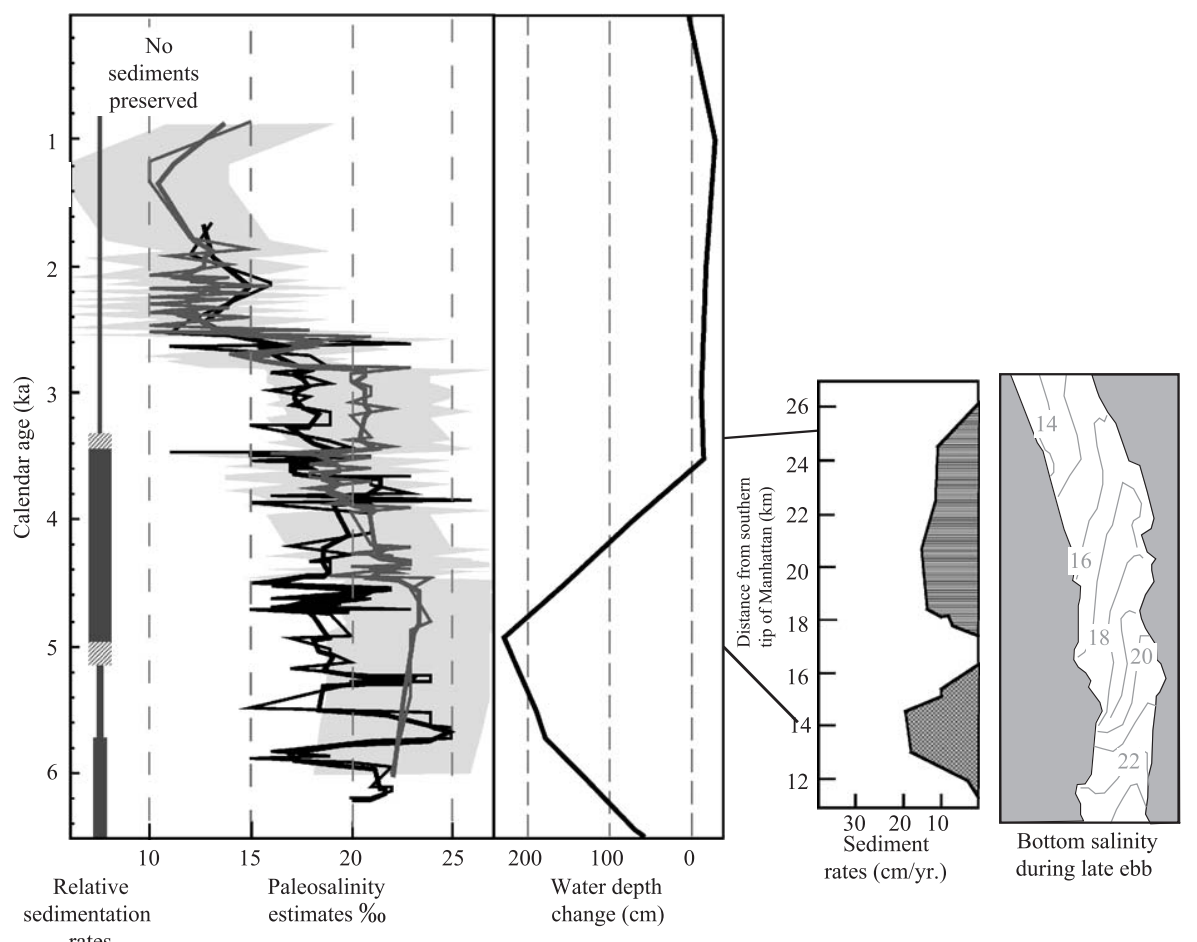

Fig. 7. Sedimentation and paleosalinity patterns are compared from SD-30 and present-day in the Hudson estuary. Sedimentation rates are shown by thickness of gray line. Hatchered portion of line is the age uncertainty. See Fig. 4 for paleosalinity and water-depth description. On the right, sedimentation rates are shown during one year due to the ETM (Woodruff et al., 2001) and a salinity profile of early summer of the Hudson estuary (Geyer et al., 1998). This provides an indication of how the paleo-ETM could be preserved as it migrated seaward through time, with the most seaward extent of the ETM and maximum landward extent of the ETM being equivalent to the base and top of the interval with high sedimentation rates, respectively. 


\subsection{Explanation for a migrating locus of sedimentation}

The locus of anomalous sedimentation associated with paleosalinities of $\sim 14 \%$ o to $\sim 22 \%$ on the western side of the estuary appears to have migrated from immediately north of the Tappan Zee Bridge to its present position in $\sim 3 \mathrm{ky}$. A plausible explanation for this pattern is the seaward migration of the ETM and the high sedimentation associated with it. The high sedimentation would have resulted in shoaling (i.e., the rate of accumulation exceeded the rate of sea-level rise), which would effectively squeeze the salinity wedge (and associated ETM) seaward and from the flats into the main channel, and increase wave-induced mixing of marine and less saline waters. Wave action would have reduced the influence of the ETM and the preservation potential of any sediment that accumulated, particularly in the area of greatest fetch between the Tappan Zee Bridge and Haverstraw Bay. This expectation is consistent with the observation that the water depth at SD-30 at $\sim 3.4$ $\mathrm{ka}$ is indistinguishable from the present depth (within $30 \mathrm{~cm}$; Fig. 4), with a reduction in the abundance of laminated sediments, and with the absence of evidence for rapid sedimentation at SD11, where the water depth was consistently less than that at SD-30. However, short cores obtained from immediately north of SD-11 and SD-30 (1-6 $\mathrm{km})$ also reveal extremely slow sedimentation and/ or sedimentary bypass since at least $2.4 \mathrm{ka}$ (McHugh et al., 2004), in spite of water depths as great as $10 \mathrm{~m}$, suggesting that wave energy may not have been the only factor limiting sediment accumulation in the Tappan Zee area during the mid- to late Holocene.

\subsection{Other factors}

Although the results from this study support the hypothesis that a paleo-ETM migrated seaward, other factors (such as climate change) may have played a role. Variations in precipitation would have influenced runoff and the location of the salinity wedge in the estuary. However, they do not explain the tendency for sediment to accumulate on the western side of the estuary, nor the apparent migration of the locus of sedimentation. Long-term changes in paleosalinity at SD-30 date from prior to $\sim 2.5 \mathrm{ka}$ are therefore probably unrelated to marked shorter time scale changes (i.e., centennial scale) in both North American and global climate since $2.5 \mathrm{ka}$ (e.g., Dwyer et al., 1996; Bond et al., 1997; Campbell et al., 1998; Mullins, 1998; Viau et al., 2002). However, higher frequency (centennial time scale) and lower amplitude paleosalinity changes observed at SD-30 between 6.4 and $3.0 \mathrm{ka}$ (Fig. 4) may have been influenced by variations in precipitation/runoff (Pekar et al., 2002). Additional studies are needed to sort out such details.

\section{Comparison between the evolution of the Hudson estuary and sequence stratigraphic models}

In standard conceptual sequence stratigraphic models (e.g., Dalrymple et al., 1992; Zaitlin et al., 1994), fine-grained sedimentation in estuaries is generally portrayed as areally widespread. Our study of the Hudson estuary suggests that this may not be true in estuaries dominated by an ETM and that at any time, estuarine sedimentation is highly localized, suggesting a more complex depositional pattern than previously indicated in estuarine stratigraphic models. High sedimentation rates are restricted to the regions where the ETM was present, while in contrast, in large portions of the estuary, sedimentation kept pace with the ever slowing rates of sealevel rise that occurred during the mid to late Holocene. Our results suggest that during the transgression in a typical estuary that contains a significant ETM, the paleosalinities and ETM would first migrate upstream. Then as the rate of sea-level rise slowed, sedimentation would begin to fill in the marginal flats (prograding toward the channel, Fig. $8 \mathrm{~B}$ ) as well as migrate progressively seaward (Fig. $8 \mathrm{~A})$ due to the migration of the ETM. This result implies that in other estuaries around the world in which a paleo ETM existed should also contain a similar pattern with the localized high sedimentation rates filling in the accommodation to wave base with both the ETM and the locus of sedimentation migrating seaward (Fig. 8). Applying this model to the standard stratigraphic models (e.g., Zaitlin et al., 1994), these high sedimentation rates (e.g., ETM) 

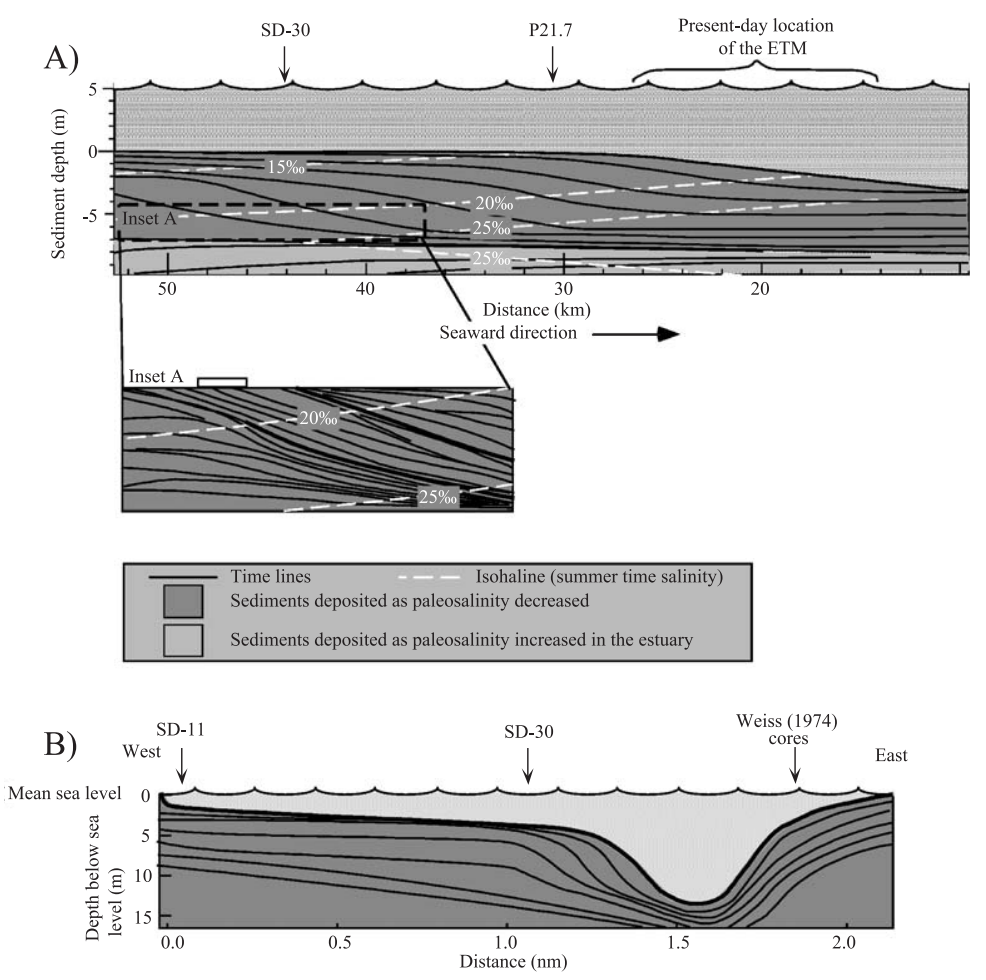

Fig. 8. (A) Generalized conceptual model of sediment accumulation in the estuary as the rate of sea-level rise slowed and the ETM migrated seaward. As the valley flooded and the estuarine conditions migrated upstream, sediments onlapped (lighter gray). As the rate of sea-level rise decreased, high sedimentation rates due to the ETM would occur first upstream and then migrate seaward (darker gray). The geometry of the prograding sediments is simplified in this diagram. It would be expected that the location of high sedimentation would be controlled by the location of the salinity that the ETM typically develops in, which in turn would depend on annual to decadal variability in precipitation/runoff. This could result in a complex geometry, consisting of mound-like to lobe-like distribution of sediments. Inset A depicts how this complex geometry may be represented in a cross-sectional view. However, if the overall shift in the ETM at the yearly time scale was small $(<10 \mathrm{~km})$, the overall sedimentation rates determined from cores would appear to be relatively constant. (B) Conceptual diagram showing a cross section of the estuary north of the Tappan Zee Bridge, based on cores SD-11, SD-30, Vema 32-03, and the cores described by Weiss (1974). The stratal geometry under the channel is conjectured, since cores from this location have not been sampled. This figure illustrates that sedimentation remained fairly constant (i.e., kept up with rising sea level) at SD-11 and cores on the east side of the estuary (Vema 32-02 and Weiss, 1974). In contrast, anomalously high sedimentation rates only occurred near SD-30 and are hypothesized to be due to the ETM. Additionally, the high sedimentation rates as a result of the trapping of the ETM would result in a filling of the western flats and a clinoformal geometry that would build out into the channel.

would represent the final phase of the transgression and the final infilling of the estuary during the transgressive phase. The low sedimentation intervals above are interpreted as the condensed interval (e.g., Allen and Posamentier, 1992), which separates the transgressive phase from the regressive phase. It should be noted that the condensed section that developed in the Hudson estuary is due to sedimentary bypass, which is the result of tidal and, in some cases, wave energy. This is in sharp contrast to the condensed section in marine settings, which is typically attributable to sediment starvation (Posamentier et al., 1988), suggesting that extremely different processes are work in the formation of the condensed section in estuaries and in marine realms (McHugh et al., 2004).

\section{Future research and directions}

This paper highlights the possible role of the ETM in the evolution of the Hudson estuary. Among issues 
that remain to be addressed is whether sedimentation was more widespread in the early Holocene Hudson estuary than is the case today; and why the rate of sedimentation near the modern ETM at the decadal time scale $(\sim 1.3 \mathrm{~mm} /$ year; R. Geyer, personal communication, 2002) is higher than that associated with the interpreted paleo-ETM $(<0.4 \mathrm{~cm} /$ year; SD-30 and P21.7 cores). Perhaps the most important aspect is that within the region of the present-day ETM, extensive dredging and construction of jetties and piers have taken place during the past century. This could skew sedimentation patterns toward higher rates (Simmons and Herrmann, 1972) and could provide an explanation why higher sedimentation rates in the last 100 years were estimated in cores taken from within the area of the present-day ETM. Land clearance has been suggested for increased sedimentation in the Chesapeake Bay and other coastal plain sites (Colman et al., 2000).

Another direction for study is how variability in seasonal runoff would affect the position of the ETM and the subsequent position of high sedimentation at geological time scales. Precipitation variability could result in a shift in the location of the ETM by a few kilometers at the annual to decadal time scale. With the present-day ETM extending over $10 \mathrm{~km}$ 's in the Hudson estuary, a shift of a few kilometers would result in little change in the sedimentation rates detected in the cores using C-14 dating (Fig. 8A, inset). However, greater variability in runoff could result in migration of the high sedimentation zone to be more pronounced (e.g., shifting $>10 \mathrm{~km}$ ). This could cause fluctuations in sedimentation rates within cores; however, it is uncertain whether $\mathrm{C}-14$ dating would be able to detect them. In the case of SD-30, a relatively constant high sedimentation rate was indicated; however, because of limitation in age resolution, it may not be able to detect such variability. Therefore, it is conceivable that some annual shifting did occur.

\section{Conclusions}

Sedimentation and paleosalinity patterns interpreted from cores from the Hudson estuary support the hypothesis that the ETM influenced sedimentation at geological time scales, and that the ETM may have migrated $\sim 20 \mathrm{~km}$ seaward between mid- and late Holocene time. Rapid sediment accumulation in the vicinity of the ETM accounts for observed shoaling, thereby pushing the saltwater wedge seaward and laterally into the channel, and increasing wave-influenced mixing of marine and less saline waters.

High sedimentation rates within the fine-grained facies in the Hudson estuary (and other estuaries that contain a significant ETM) is spatially a highly localized phenomena within the area that the ETM existed, concentrating the sedimentary accumulation at any specific time in a relatively small portion of the estuary over long-term time scales. This provides a link between the processes occurring in the estuary today (namely the ETM) and what is ultimately preserved in the geologic record. Finally, understanding the ETM can be important for environmental geology, such as providing a better understanding of the deposition and burial of contaminated sediment patterns in the Hudson estuary as well as changes in sedimentation patterns during potential future global sea-level rise.

\section{Acknowledgements}

We thank Orange and Rockland County Gas and Electric for donating the SD cores to Lamont-Doherty Earth Observatory. This research was supported by the Hudson River Foundation, by the Climate Center at Lamont-Doherty Earth Observatory, and other institutional funds. We warmly thank L. de Weerd, R. Geyer, J. Shulmeister and D. Willard for their thoughtful and in sightful comments on an earlier version of this paper. We acknowledge National Ocean Sciences Accelerator Mass Spectrometry Facility (NOSAMS) for C-14 ages, and thank D. Peteet and J.L. Rubenstone for sharing their data. Lamont-Doherty Earth Observatory Contribution Number 6614.

\section{References}

Allen, G.P., Posamentier, H.W., 1992. Transgressive facies and sequence architecture in mixed tide- and wave-dominated incised valleys: example from the Gironde Estuary, France. In: Darlymple, R.W., Boyd, R., Zaitlin, B.A. (Eds.), Incised-Valley 
Systems: Origin and Sedimentary Sequences. SEPM Spec. Publ. 51, 225-239.

Banner, F.T., Culver, S.J., 1978. Quaternary Haynesina N. Gen. and Paleogene Protelphidium Haynes; Their Morphology, Affinities and Distribution. Journal of Foraminiferal Research 8, $177-207$.

Bond, G., Showers, W., Cheseby, M., Lotti, R., Almasi, P., deMenocal, P., Priore, P., Cullen, H., Hajdas, I., Bonani, G., 1997. A pervasive millennial-scale cycle in North Atlantic Holocene and glacial climates. Science 278, 1257-1266.

Bradley, W.H., Cooke, P., 1957. Living and ancient populations of the clam Gemma gemma in a Maine coast tidal flat. U.S. Department of the Interior, Fish, and Wildlife Survey. Fishery Bulletin 137 , vol. 58, pp. 304-334.

Broecker, W.S., 1963. ${ }^{14} \mathrm{C} /{ }^{12} \mathrm{C}$ ratios in surface ocean water. Natural Research Council, Publication, vol. 1075. National Academy of Science, Washington, DC, pp. 138-149.

Brown, J., Colling, A., Park, D., Phillips, J., Rothery, D., Wright, J., 1995. Waves, Tides, and Shallow-Water Processes. The Open University, Oxford, UK.

Buzas, M.A., 1965a. The distribution and abundance of foraminifera in Long Island Sound. Smithsonian Miscellaneous Collections $149,1-37$.

Buzas, M.A., 1965b. Foraminifera from Late Pleistocene clay near Waterville, Maine. Smithsonian Miscellaneous Collections 145, $1-30$.

Buzas, M.A., Culver, S.J., Isham, L.B., 1985. A comparison of fourteen Elphidiid (Foraminiferida) taxa. Journal of Paleontology 59, 1075-1090.

Campbell, I.D., Campbell, C., Apps, M.J., Rutter, N.W., Bush, A.B.G., 1998. Late Holocene $\sim 1500$ yr. climatic periodicities and their implications. Geology 26, 471-475.

Coch, N.K., 1986. Sediment characteristics and facies distributions in the Hudson system. Northeastern Geology 8, 109-129.

Coch, N.K., Barton, K.G., Longoria, A.G., 1991. Holocene evolution of the Hudson River estuary. Journal of Coastal Research $11,55-71$.

Colman, S.M., Baucom, P.C., Bratton, J.F., Cronin, T.M., McGeehin, J.P., Willard, D., Zimmerman, A.R., Vogt, P.R., 2000. Radiocarbon dating, chronologic framework, and changes in accumulation rates of Holocene estuarine sediments from the Chesapeake Bay. Quaternary Research 57, 58-70.

Dalrymple, R.W., Zaitlin, B.A., Boyd, R., 1992. Estuarine facies models, conceptual basis and stratigraphic implications. Journal of Sedimentary Petrology 62, 1130-1146.

Dwyer, T.R., Mullins, H.T., Good, S.C., 1996. Paleolclimatic implications of Holocene lake-level fluctuations, Owasco Lake, New York. Geology 24, 519-522.

Ellison, R.L., Nichols, M.M., 1976. Modern and Holocene Foraminifera in the Chesapeake Bay Region. First International Symposium on Benthonic Foraminifera of Continental Margins, Part A. Maritime Sediments Special Publication 1, 131-151.

Fairbanks, R.G., 1982. The origin of continental shelf and slope water in the New York Bight and Gulf of Maine: evidence from $\mathrm{H}_{2}^{18} \mathrm{O} / \mathrm{H}_{2}^{16} \mathrm{O}$ ratio measurements. Journal of Geophysical Research 87, 5796-5808.

Fenster, M.S., FitzGerald, D.M., 1996. Morphodynamics, stratigra- phy, and sediment transport patterns of the Kennebec River estuary, Maine, USA. Sedimentary Geology 107, 99-120.

Geyer, W.R., 1993. The importance of suppression of turbulence by stratification on the estuarine turbidity maximum. Estuaries 16, $113-125$.

Geyer, W.R., Signell, R.P., Kineke, G.C., 1998. Lateral trapping of sediment in a partially mixed estuary. In: Dronker, J., Scheffers, M. (Eds.), Physics of Estuaries and Coastal Seas, Proceedings of the 8th International Biennial Conference on Physics of Estuaries and Coastal Seas, pp. 115-124.

Geyer, R.W., Traykovski, P., Sommerfield, C.L., 2001. Frontal convergence causes sediment trapping in the Hudson River Estuary. Geological Society of America Annual Meeting 33, A406.

Grabemann, I., Uncles, R.J., Krause, G., Stephens, J.A., 1997. Behavior of turbidity maxima in the Tamar (UK) and Weser (F.R.G.) Estuaries. Estuarine, Coastal and Shelf Science 45, 235-246.

Green, R.H., Hobson, K.D., 1970. Spatial and temporal structure in a temperate intertidal community, with special emphasis on Gemma gemma (Pelecypoda: Mollusca). Ecology 51, 999-1011.

Le Bris, H., Glemarec, M., 1996. Marine and brackish ecosystems of South Brittany (Lorient and Vilaine Bay) with particular reference to the effect of the turbidity maxima. Estuarine, Coastal and Shelf Science 42, 737-753.

Loeblich, A.R., Tappan, H., 1988. Foraminiferal Genera and their Classification. Van Nostrand Reinhold, New York.

McHugh, C.M.G., Pekar, S.F., Christie-Blick, N., Ryan, W.B.F., Carbotte, S., Bell, R.E., 2004. Spatial variations in a condensed interval between estuarine and open-marine settings: Holocene Hudson River Estuary and adjacent continental shelf. Geology 32, $169-172$.

Mullins, H.T., 1998. Environmental change controls of lacustrine carbonate, Cayuga Lake, New York. Geology 26, 443-446.

Murray, J.W., 1991. Ecology and Paleoecology of Benthic Foraminifers. Wiley, New York.

Newman, W., Thurber, D.H., Zeiss, H.S., Rokach, A., Musich, L., 1969. Late quaternary geology of the Hudson River Estuary: a preliminary report. Transactions of the New York Academy of Sciences 31, 548-570.

Nichols, M.M., 1972. Sediments of the James River estuary, Virginia. Geological Society of America Memoir 133, 169-210.

Olsen, C.B., Simpson, H.J., Bopp, R.F., Williams, S.C., Peng, T.H., Deck, B.L., 1978. A geochemical analysis of the sediments and sedimentation in the Hudson Estuary. Journal of Sedimentary Petrology 48, 401-418.

Owen, R., Kennedy, H., Richardson, C., 2002. Experimental investigation into partitioning of stable isotopes between scallop (Pecten maximus) shell calcite and seawater. Palaeogeography, Palaeoclimatology, Palaeoecology 185, 163-174.

Parker, F.L., 1952. Foraminiferal distribution in the Long Island Sound-Buzzards Bay area. Bulletin of the Museum of Comparative Zoology 106, 427-473.

Pekar, S.F., Gonzalez-McHugh, C.M., Christie-Blick, N., Jones, M.C., Lynch-Stieglitz, J., 2002. Using salinity estimates and sedimentary data to evaluate the processes that controlled the evolution of Hudson River estuary during the mid-Holocene. EOS, Transactions American Geophysical Union, F-787. 
Peltier, W.R., 1998. Postglacial variations in the level of the sea: implications for climate dynamics and solid-earth geophysics. Reviews of Geophysics 36, 603-689.

Peltier, W.R., 1999. Global sea level rise and glacial isostatic adjustment. Global and Planetary Change 20, 93-123.

Posamentier, H.W., Jervey, M.T., Vail, P.R., 1988. Eustatic controls on clastic deposition: I. Conceptual framework. In: Wilgus, C.K., Hastings, B.S., Kendall, C.G.St.C., Posamentier, H.W., Ross, C.A., Van Wagoner, J.C. (Eds.), Sea-Level Changes: An Integrated Approach. SEPM Special Publication 42, 109-124.

Postma, H., 1967. Sediment transport and sedimentation in the estuarine environment. In: Lauff, G.H. (Ed.), Estuaries, American Association for the Advancement of Science, Washington, DC, pp. $158-179$.

Ridge, J.C., Franzi, D.A., Muller, E.H., 1991. Late Wisconsinian, pre-valley heads glaciation in the western Mohawk Valley, Central New York, and its regional implications. Geological Society American Bulletin 103, 1032-1048.

Ristich, S.S., Crandall, M., Fortier, J., 1977. Benthic and epibenthic macroinvertebrates of the Hudson River. Estuarine and Coastal Marine Sciences 5, 255-266.

Sanford, L.P., Suttles, S.E., Halka, J.P., 2001. Reconsidering the physics of the Chesapeake Bay estuarine turbidity maximum. Estuaries 24, 655-669.

Scott, D.B., Medioli, F.S., Schaffer, C.T., 1977. Temporal changes in foraminiferal distributions in Miramichi River estuary, New Brunswick. Canadian Journal of Earth Science 14, 1566-1587.

Scott, D.B., Schaffer, C.T., Medioli, F.S., 1980. Eastern Canadian estuarine foraminifera: a framework for comparison. Journal of Foraminiferal Research 10, 205-234.

Selmer, G.P., 1959. Studies of the Anatomy and Life History of the Gem Clam, Gemma gemma (Totten). PhD thesis, Rutgers University, New Jersey.

Selmer, G.P., 1967. Functional morphology and ecological life history of the gem clam, Gemma gemma (Eulamellibranchia: Veneridae). Malacologia 5, 137-233.

Simmons, H.B., Herrmann, F.A., 1972. Effects of man-made works on the hydraulic, salinity, and shoaling regimens of estuaries. Geological Society of America Memoir 133, $555-570$.
Stuiver, M., Reimer, P.J., Bard, E., Beck, J.W., Burr, G.S., Hughen, K.A., Kromer, B., McCormac, F.G., Plicht, J.V.D., Spurk, M., 1998. INTCAL98 Radiocarbon Age Calibration, 24,000-0 cal BP. Radiocarbon 40, 1041-1083.

Todd, R., Low, D., 1981. Marine Flora and Fauna of the Northeastern United States. Protozoa: Sarcodina: Benthic Foraminifera. NOAA Technical Report NMFS Circular 439. U.S. Department of Commerce.

Uchupi, E., Driscoll, N., Ballard, R.D., Bolmer, S.T., 2001. Drainage of late Wisconsin glacial lakes and the morphology and late quaternary stratigraphy of the New Jersey-southern New England continental shelf and slope. Marine Geology 172, 117-145.

Uncles, R.J., Stephens, J.A., 1993. Nature of the turbidity maximum in the Tamar Estuary, UK. Estuarine, Coastal and Shelf Science 36, 413-431.

Viau, A.E., Gajewski, K., Fines, P., Atkinson, D.E., Sawada, M.C., 2002. Widespread evidence of $1,500 \mathrm{yr}$. climate variability in North America during the past 14000 yr. Geology 30, 455-458.

Weiss, D., 1974. Late Pleistocene stratigraphy and paleoecology of the Lower Hudson Estuary. Geological Society of America Bulletin $85,1561-1570$.

Weiss, D., 1976. Distribution of benthonic foraminifera in the Hudson River estuary. First International Symposium on Benthonic Foraminifera of Continental Margins. Maritime Sediments Special Publication 1, 119-129.

Weiss, D., Rachlin, J.W., Coch, N.K., 1975. The Hudson Estuary. Guidebook for the 39th Annual Meeting of New England Intercollegiate Field Conference.

Weiss, D., Geitzenauer, K., Shaw, F.C., 1978. Foraminifera, diatom, and bivalve distribution in recent sediments of the Hudson estuary. Estuarine and Coastal Marine Science 6, 393-400.

Woodruff, J.D., Geyer, W.R., Sommerfield, C.K., Driscoll, N.W., 2001. Seasonal variation of sediment deposition $n$ the Hudson River estuary. Marine Geology 179, 105-119.

Zaitlin, B.A., Dalrymple, R.W., Boyd, R., 1994. The stratigraphic organization of incised valley systems associated with relative sea-level change. In: Dalrymple, R.W., Boyd, R., Zaitlin, B.A. (Eds.), Incised Valley Systems, Origins, and Sedimentary Sequences. Special Publication Society of Economic Paleontologists and Mineralogists 51, 45-60. 